Bull. Mater. Sci., Vol. 17, No. 2, April 1994, pp. 171-179. (C) Printed in India.

\title{
In vivo and in vitro evaluation of a biomachinable glassceramic
}

\author{
K RATHINAM, R SIVAKUMAR and V SARASWATI*† \\ Sree Chitra Tirunal Institute of Medical Sciences and Technology, Trivandrum 695012, India \\ ${ }^{\dagger}$ Defence Metallurgical Research Laboratory, Kanchanbagh, Hyderabad 500258 , India \\ MS received 4 October 1993
}

Abstract. In this paper we describe the toxicological tests done on a machinable glassceramic, prepared at the Defence Metallurgical Research Laboratory. Tests show no toxicity and biocompatibility is inferred.

Keywords. Machinable glassceramic; bioglassceramic; biomaterial; toxicology tests.

\section{Introduction}

Materials used for replacing organs or functions of the body for short or long durations are called biomaterials. Bioactive glasses and glassceramics are being used increasingly for ossicular bone replacement prostheses, maxillofacial reconstruction, periodontal packing, middle ear and dental implants, etc. (Hulbert et al 1987).

Glassceramics combine the advantages of both glasses and ceramics. They are chemically stable and corrosion-resistant. They can be processed to near-netshape and full density by conventional glass melting and forming routes. On heat treatment the glass transforms to a glassceramic with in-grown crystalline phases. The conversion of glass to a glassceramic results in volume shrinkage, which is normally less than $4 \%$ (Saraswati and Sriram 1989). Hence the cast can be fabricated to a tight tolerance, which is found to be an advantage in shaped implants and denture casting. They are devoid of pores, voids and microcracks. The densities usually range between 2.4 and $2.8 \mathrm{~g} / \mathrm{cm}^{3}$. They are light compared to bioinert alumina. Owing to the presence of crystalline phases in the glass matrix the glassceramic has a composite nature and has a higher strength compared to glass. By changing the composition and heat treatment steps, the properties of glassceramics can be tailored to suit an end use as the properties are controlled by the size, morphology and volume fraction of crystalline phases in the glass matrix (McMillan 1979). Hydroxylapatite or fluoroapatite phase in bulk or surface of glass renders the material biocompatible (Kokubo 1990) and/or bioactive because the bone contains calcium phosphates. Mechanical tests carried out on the glassceramic prepared at DMRL showed the material to be machinable (Saraswati et al 1993). The presence of fluormica phase renders it machinable (Saraswati et al 1991). Here we report on the material and the toxicology tests done to ascertain its biocompatibility.

\section{Material processing}

A batch composition consisting of silica, alumina, calcia, magnesia, phosphate and fluoride was melted at $1500^{\circ} \mathrm{C}$. Melting was done in platinum crucibles. The melt

\footnotetext{
*For correspondence
} 
was cast on plates or dies. The heat treatment of the glass (cast melt) was done in four steps. The temperatures were chosen on the basis of DTA measurements. Annealing was carried out at $600^{\circ} \mathrm{C}$ followed by heating at $800^{\circ} \mathrm{C}$ and $850^{\circ} \mathrm{C}$ for nucleation of fluormica and apatite phases. Final heating ranged between 950 and $1050^{\circ} \mathrm{C}$ for appropriate size and volume fraction of crystallites. After the heat treatment and characterization the machinability was tested and indexed. Details of material preparation and tests are given elsewhere (Saraswati et al 1993).

\section{Characterization}

The density of the glassceramic, measured by the displacement method, was $2.55 \mathrm{~g} / \mathrm{cm}^{3}$. The change in density from glass to glassceramic was less than $2 \%$. X-ray powder diffraction was used for identifying the crystalline phases (figure 1). The initial glass was amorphous. Apatite, $\mathrm{Ca}_{5}\left(\mathrm{PO}_{4}\right) \mathrm{F} / \mathrm{OH}$, and fluormica, $\mathrm{KMg}_{3} \mathrm{AlSi}_{3} \mathrm{O}_{10} \mathrm{~F}_{2}$, phases were present in the heat-treated glass. The relative contents of apatite and fluormica phases could also be estimated from XRD patterns.

FTIR patterns complement and confirm the conclusions from XRD (figure 2). Infrared absorption spectra relate to the vibrations of molecular groupings. Absorption peaks around $1050,800,700$ and $470 \mathrm{~cm}^{-1}$ are from stretch and bending vibration modes of $\mathrm{SiO}_{4}$ groups in mica and glass matrix whereas 603 and $572 \mathrm{~cm}^{-1}$ absorptions are from $\mathrm{PO}_{4}$ groups in apatite. Microstructure (figure 3) and EDX analysis further confirmed the presence of fluormica and apatite phases. The relative proportions of these phases determine the ease of machinability. Machinability index was determined as described earlier (Saraswati et al 1993). The machinability arises from the cleavable nature of fluormica phase and the composite nature of the material. Randomly oriented crystallites, which are interlocked and uniformly distributed in the glass matrix, cause deflection and localization of cracks. The machinability is through localized granulation. The ease of machining is dependent on the microstructure and the machinability index is a reflection of it and the relative volume of glass and crystalline phases. Thermal expansion coefficient measured in the range $20-800^{\circ} \mathrm{C}$ was $95 \times 10^{-7} /{ }^{\circ} \mathrm{C}$. Knoop indentation hardness at $100 \mathrm{~g}$ load was measured on the polished samples. Table 1 summarizes the results of these measurements in comparison

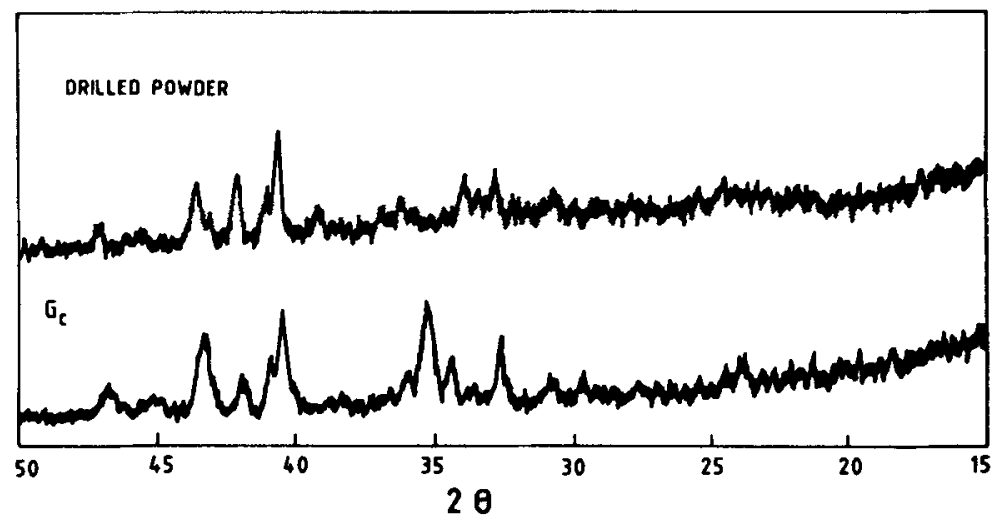

Figure 1. XRD of bioglassceramic in glassceramic and powder drilled from it. 


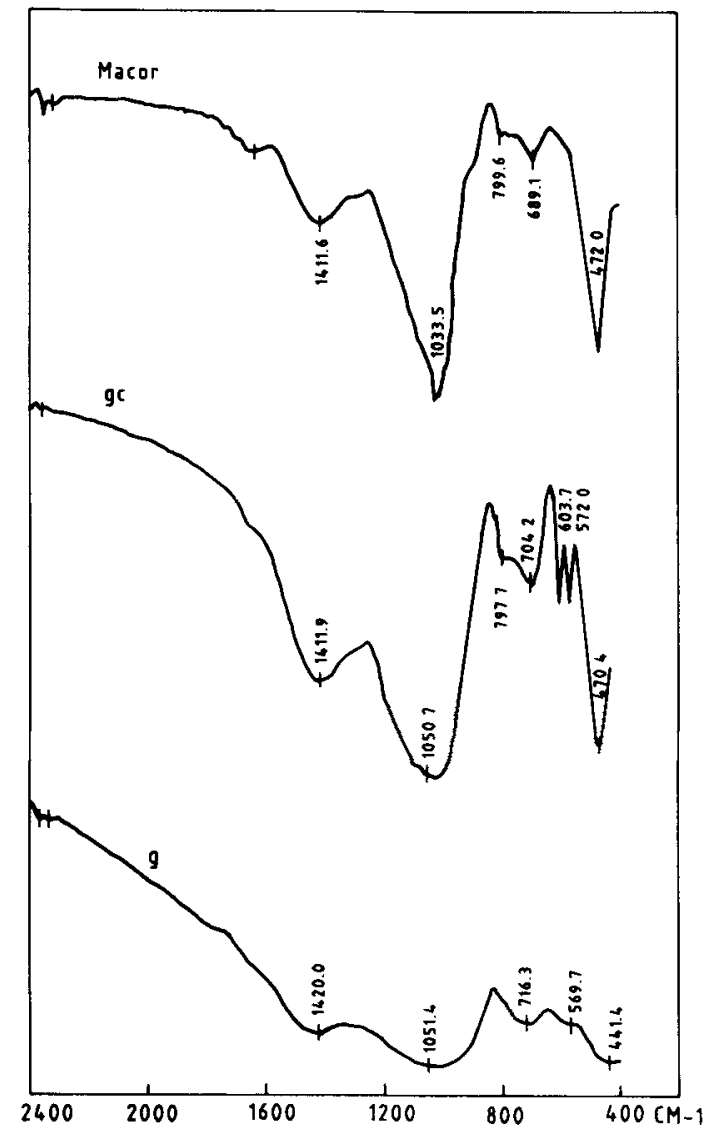

Figure 2. FTIR of bioglassceramic: glass and glassceramic compared with Macor.

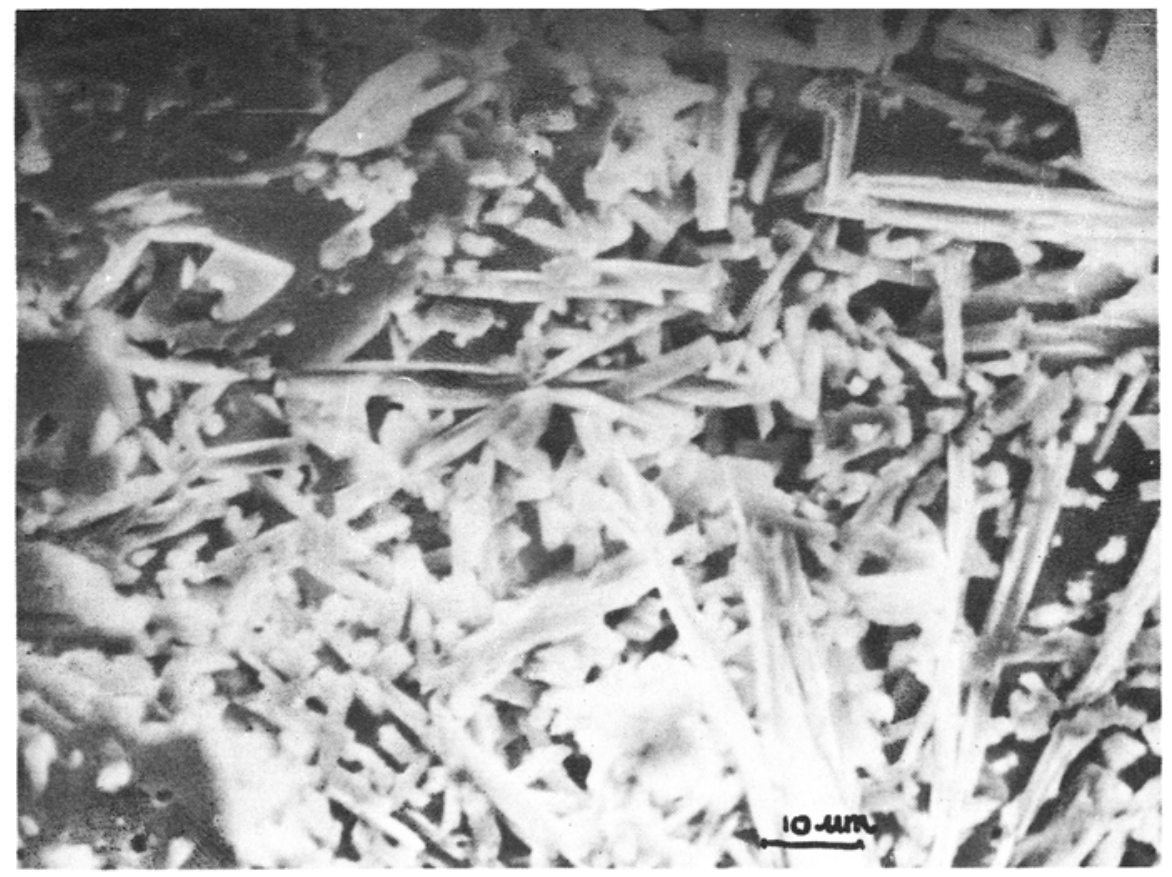

Figure 3. Micrograph of the etched, fracture surface of glassceramic, scale $1 \mathrm{~cm}=10 \mu \mathrm{m}$. 
Table 1. Comparison of the properties of glassceramic with tooth enamel.

\begin{tabular}{lcccc}
\hline & Bioglassceramic & & Macor & Tooth enamel \\
\hline XRD phase & Fluormica, apatite & Fluormica & Apatite \\
Density $\left(\mathrm{g} / \mathrm{cm}^{3}\right)$ & $2 \cdot 55$ & $2 \cdot 52$ & $2 \cdot 9-3$ \\
Hardness $\left(\mathrm{kg} / \mathrm{mm}^{2}\right)$ & 295 & 250 & 370 \\
Therm. exp. coeff. & 95 & 110 & 110 \\
$\left(10^{-7} /{ }^{\circ} \mathrm{C}\right)$ & & & \\
Flex. str. $(\mathrm{MPa})$ & 86 & 102 & \\
\hline
\end{tabular}

to Macor, a commercial machinable glassceramic and tooth enamel (Manabe et al 1987). The glassceramic was soaked in SBF (simulated body fluid) for more than 30 days (Kokubo 1990). There was neither weight loss nor any change in the XRD or FTIR spectra. This material can be utilized to fabricate implants of various types and for repair of defects as it is machinable and can be shaped like any metal. It has better chemical resistance and in density it is lighter compared to metals, alloys and ceramics. Since this glassceramic contains apatite phase it could be bioreactive. Hence better fixing of implants can be expected. Any material intended for bioapplication needs to be tested for body response. The evaluation for biocompatibility was done as follows.

\section{In vitro and in vivo evaluations}

Any foreign substance evokes a response in the body, which could be pathologic, systemic, immunologic, metabolic or toxic in nature. Toxicology tests are essential and the details of tests are dependent on the application desired for the implant material. As the glassceramic can be used for both dental and orthopaedic applications, the following tests were carried out.

\subsection{Haemolysis test}

This test is to ensure that the implant material does not cause significant lysis (i.e. dissolution) of the red blood cells. Any material which causes haemolysis of $>5 \%$ is hazardous to the patient. In vitro haemolytic potential test was effected similar to the method described by O'Leavy and Guess (1980) and Vedanarayan et al (1983). With this glassceramic haemolysis was found to be $0.04 \%$, well within the permissible limit. This glassceramic can hence be classified as nonhaemolytic.

\subsection{Skin sensitization}

These tests evaluate the allergenic potential of the implant material when in contact with tissues or body fluids. Using guinea pigs, standard prescribed tests (Magnusson and Kligman 1969) were conducted. No allergic reaction was observed for the glassceramic. 
Table 2. Cell counts in test samples.

\begin{tabular}{lcc}
\hline Test & Gran. cells $\left({ }^{\circ}\right)$ & Degran. cells $(\%)$ \\
\hline Neg. control & 79 & 21 \\
Glassceramic & 76 & 24 \\
Pos. control & 68 & 32 \\
\hline
\end{tabular}

\subsection{Mast cell degranulation}

In vitro mast cell technique was used to estimate the cytotoxic potential, which reflects on the adverse effects of the implant on the cells. These tests are for assessing the degranulating potential (disruption) of the mast cells, which is an index of cytotoxicity. Saline extract of glassceramic material was prepared as per standards (USP 1985). A Wistar albino rat was sacrificed and a piece of gut with mesentery was removed. One mesenteric piece each was inserted in three test tubes with reagent/solution as described below and incubated at $37^{\circ} \mathrm{C}$ for $15 \mathrm{~min}$. One test tube was the negative control containing $10.0 \mathrm{ml}$ Ringer-Locke solution $+1.0 \mathrm{ml}$ normal saline. Another test tube contained $10.0 \mathrm{ml}$ Ringer-Locke solution $+1.0 \mathrm{ml}$ normal saline extract of glassceramic. Extraction was at $70^{\circ} \mathrm{C}$ for $24 \mathrm{~h}$. A positive control with $10.0 \mathrm{ml}$ RingerLocke solution $+1.0 \mathrm{ml} 25 \mathrm{mg} \%$ barium methacrylate was the third tube. After the incubation period the tissues were separated, stained and studied. Table 2 and the photographs (figure 4) reveal no significant degranulation due to glassceramic indicating no toxicity.

\subsection{Intramuscular implantation}

The aim is to evaluate the reaction of living tissue to the material implanted (Autrian 1977; ADAD 1979). $1 \times 1 \times 10 \mathrm{~mm}^{3}$ strips of glassceramic were implanted on either side of the paravertebral muscle of healthy albino rabbits, each containing four test pieces, two negative controls (ruby) and two shams (figure 5). After one week and one, three and six months the animals were sacrificed. The tissue along with the implant were extracted and studied for evidence of film, haemorrhage, necrosis and encapsulation. Table 3 lists the histopathological responses of tissues implanted with test material, sham and negative control.

Despite a severe inflammatory response observed at the end of one week in the tissue surrounding test, sham and control operated areas, there was gradual healing with time and no difference was seen with respect to ruby control in the one- and sixmonth samples. This demonstrates the absence of irritant foreign body reaction. Neutrophil activity was also absolutely nil showing the material to be resistant to biodegradation.

After implantation, after a lapse of 1 week and 1, 3 and 6 months the implants were found unattached to the surrounding skeletal muscle. They could be removed easily and the implant surface was smooth. Necrosis of adjacent skeletal muscle with acute chronic inflammation was seen one week after implantation. The inflammatory infiltrate mainly consisted of macrophages and lymphocytes. Repair could be evidenced from fibroblasts and fibrocytes in the periphery (table 3 ). The inflammatory reaction 

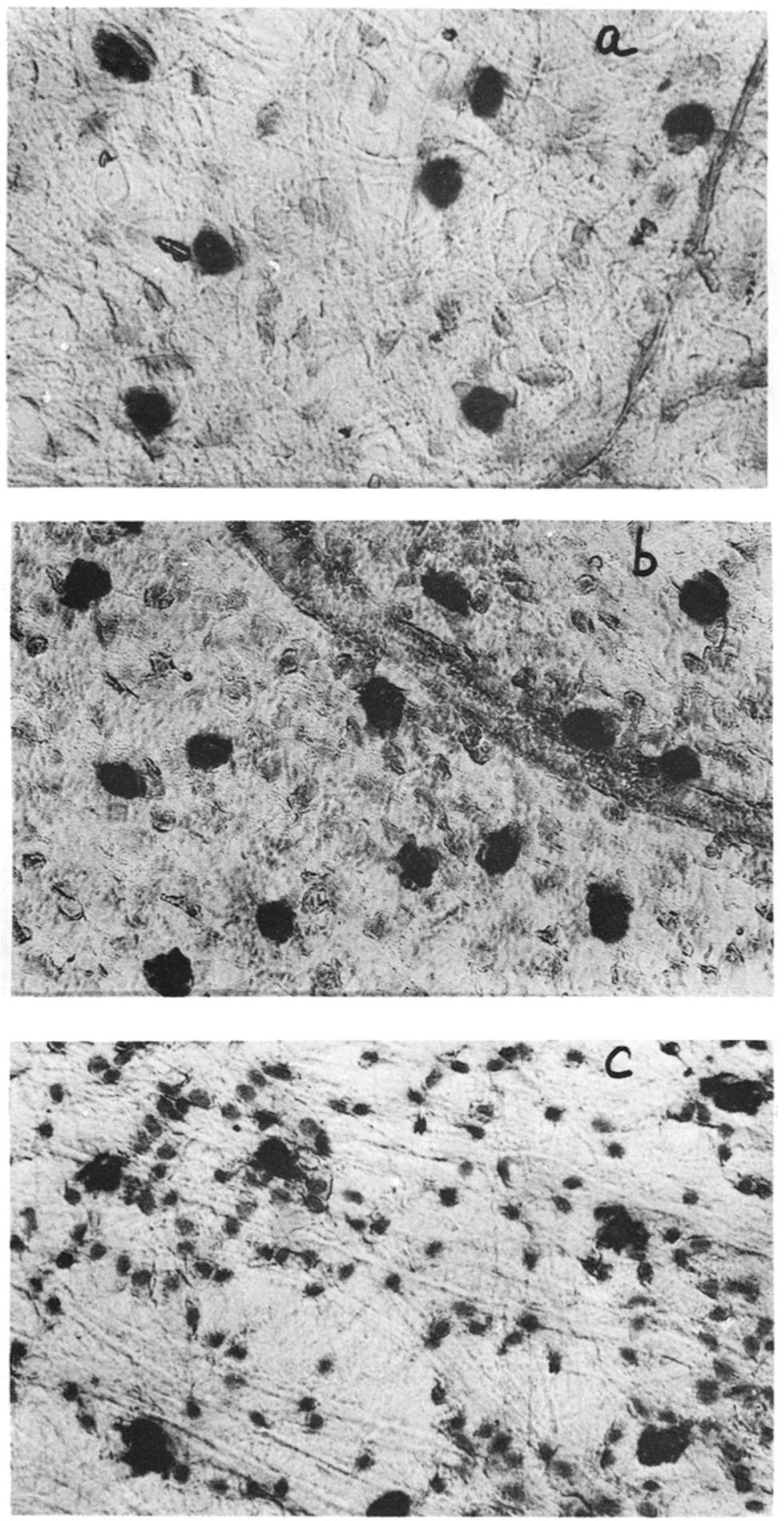

Figure 4. Photomicrograph of degranulation tests; $\mathbf{a}, \mathbf{b}, \mathbf{c}$ are negative, test and positive controls $(\times 100)$. 
DORSAL VIEW OF CLIPPED AND ANAESTHETISED RABBIT

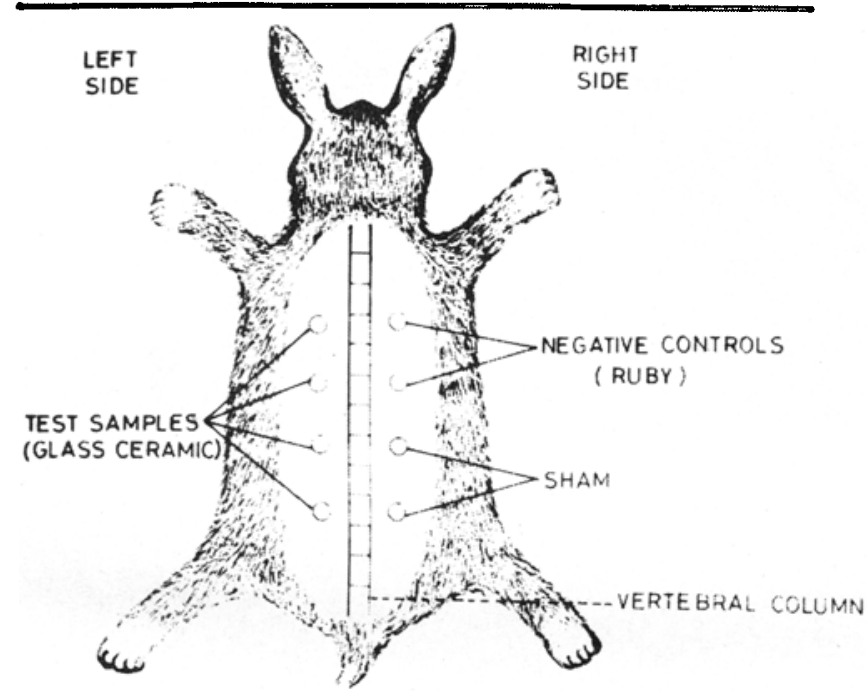

Figure 5. Implant positions of sham, ruby(control) and glassceramic.

Table 3. Cellular response to implant after 1 week and 1, 3,6 months.

\begin{tabular}{lcccc}
\hline Histopathology & 1 week & 1 month & 3 months & 6 months \\
\hline Macrophages & $3+$ & $2+$ & + & 0 \\
Lymphocytes & $1+$ & $2+$ & 0 & 0 \\
Plasma cells & 0 & $1+$ & 0 & 0 \\
Fibroblasts & $3+$ & $2+$ & $1+$ & 0 \\
Fibrocytes & $2+$ & $2+$ & $1+$ & $1+$ \\
\hline
\end{tabular}

Scoring: Based on a $0-3$ scale: 0 , item absent; + , item occasionally present; $1-3+$, item present mild to a high degree.

subsided after a month with a moderate infiltrate and occasional plasma cell (figure 6a). A capsule of mature collagen surrounded the implant with a few fibroblasts and fibrocytes. The thickness of the capsule decreased in 3 and 6 months (figure 6b). No adverse tissue response was noted.

\section{Conclusions}

The glassceramic was inferred to be biocompatible. Since the responses shown by the glassceramic material in both in vitro and in vivo tests up to six months implantation were equal to or less than the response to the control material (viz. ruby) it has been concluded that this glassceramic is nontoxic and biocompatible. 


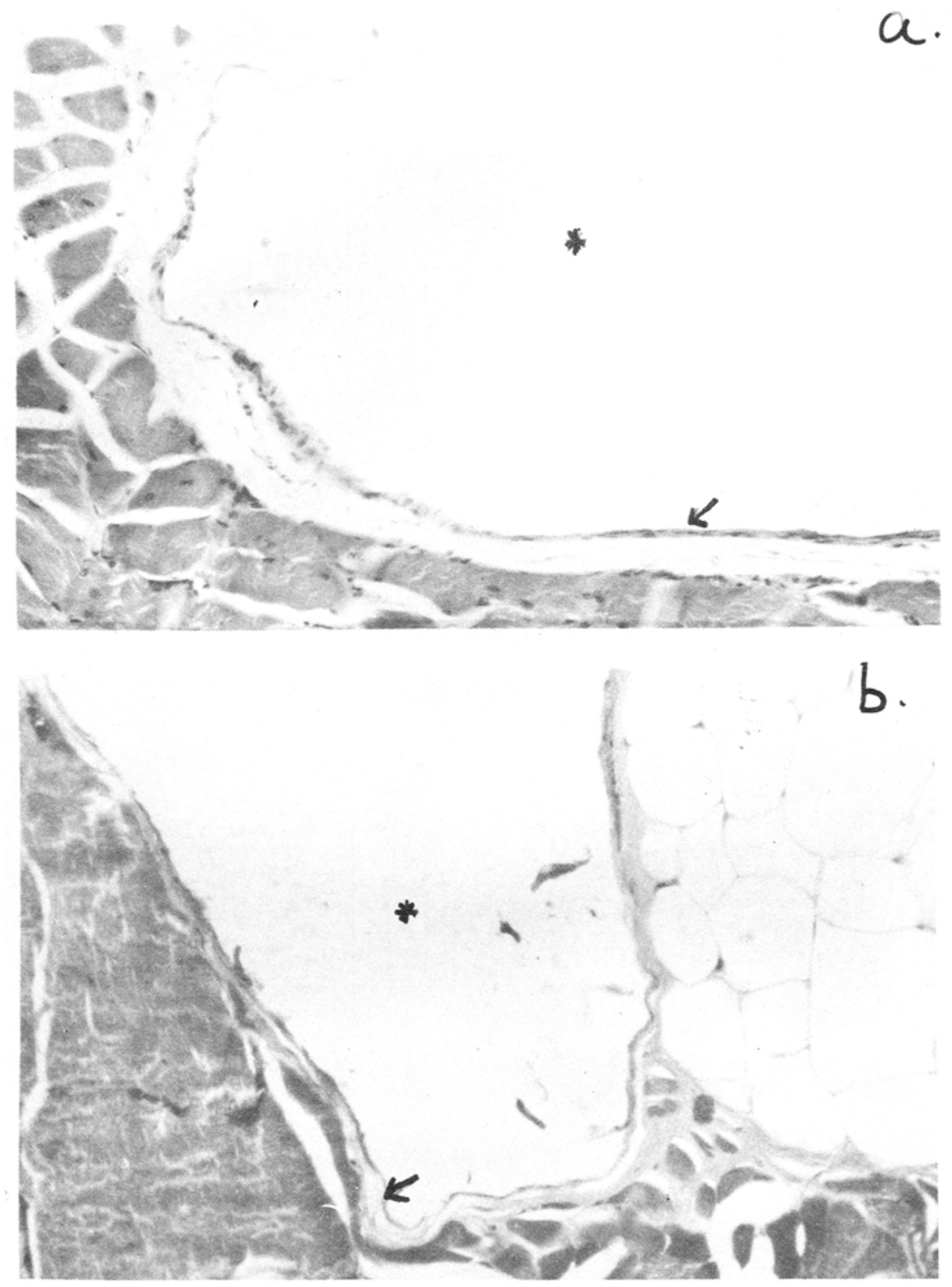

Figure 6. Photomicrograph of implant site after (a) 1 month and (b) 6 months showing reduction in wall thickness.

\section{Acknowledgements}

We are grateful to Dr Mira Mohanty for histopathological investigations. We are thankful to the Director, DMRL, and the Director, SCTIMST, for support and encouragement. 


\section{References}

Autrian J 1977 Artific. Organ 153

American Dental Association Document 1979 41; 1979 J. Am. Dent. Assoc. 99697

Hulbert S F, Bokros J C, Hench L L, Wilson J and Heimke G 1987 in High tech ceramics (ed.) P Vincenzini (Amsterdam: Elsevier Science Publishers)

Kokubo $1990 \mathrm{~J}$. Non-Cryst. Solids 120138

Manabe M, Shigematsu M and Kobayashi S 1987 in High tech ceram. (od.) P Vincenzini (Amsterdam: Elsevier Science Publishers) 63

Magnusson B and Kligman A M $1969 \mathrm{~J}$. Invest. Dermat. 52268

Mcmillan P W 1979 in Glassceramics (London: Academic Press)

O'Leavy and Guess W L 1968 J. Pharm. Sci. 5712

Saraswati V and Sriram 1989 Met. Mater. Process. 121

Saraswati V, Anjaneyulu K V S R and Visweswararao N V 1993 Met. Mater. Process 567

Saraswati V, Anjaneyulu K V S R and Visweswararao N V 1991 Met. Mater. Process 375

United States Pharmacopeia 1985 (Rockvilli: USA pharmacopeial convention, Inc.) xxi edition, p $1235-6$

Vedanarayanan P V, Rathinam K and Fernandez A C 1983 Bull. Mater. Sci. 597 